\title{
On Tampering with Nature
}

\author{
Jules Janick \\ Department of Horticulture, Purdue University, West Lafayette, IN 47907-1165
}

Perdita ...the fairest flowers o' the season Are our carnations and streak'd gillyvors, Which some call Nature's bastards. Of that kind our rustic garden's barren, and I care not to get slips of them.

Polixenes Wherefore, gentle maiden, Do you neglect them?

Perdita For I have heard it said,

There is an art which in their piedness shares

With great creating Nature.

Polixenes Say there be;

Yet Nature is made better by no mean

But Nature makes that mean; so over that art

Which you say adds to Nature, is an art

That Nature makes. You see, sweet maid, we marry

A gentler scion to the wildest stock,

And make conceive a bark of baser kind

By bud of nobler race. This is an art

Which does mend Nature-change it rather; but

The art itself is Nature.

Perdita So it is.

Polixenes Then make your garden rich in gillyvors,

And do not call them bastards.

Perdita I'll not put

The dibble in earth to set one slip of them; No more than were I painted I would wish This youth should say 'twere well, and only therefore

Desire to breed by me.

[Shakespeare, The Winter's Tale (act IV, scene IV, lines 81-103)]

It is springtime in Bohemia. Perdita, showing off her garden to Polixenes, the King in disguise, makes it absolutely clear the loathing she feels for streaked or variegated gillyflowers [pinks (Dianthus)], the product, apparently, of the new technique of cross breeding. In a memorable reply, Polixenes gently points out that the art involved in changing and improving nature is itself part of nature and cites grafting as an example. Perdita will have none of it.

Received for publication 20 June 1994. Accepted for publication 8 July 1994 . Viewpoints are published in HortScience to provide members of the American Society for Horticultural Science an opportunity to share their experiences and comments on matters of concern to horticulturists. These are not statements of official Society policy, nor do they necessarily reflect the views of a majority of the Society's members. The cost of publishing this paper was defrayed in part by the payment of page charges. Under postal regulations, this paper therefore must be hereby marked advertisement solely to indicate this fact.
In this extraordinary passage, Shakespeare wonderfully expresses the conflict between nature and science, between natural and unnatural. We smile at Perdita's innocence vis-avis the King's sophistication, yet the issue is as current today as it was at the start of the 17th century. There are many among us who are still uncomfortable with those who tamper with nature, believing it at best unwise, if not dangerous-and at worst, unethical, even immoral. The deep fear of birth defects and monstrosities probably is at the basis of this concern. Dread of the unforeseen consequences of uncontrolled genetic manipulation in plants has been exploited in popular culture, e.g., the killer tomatoes and the man-eating Audrey II from the macabre musical Little Shop of Horrors.

The consequences of genetic manipulation are no longer an arcane academic issue but a tremendous concern because the species barrier to the exchange of genetic information has been broken by advances in biotechnology. Of course, the lowly bacterium Agrobacterium tumefaciens, the pathogen responsible for crown gall disease, has long practiced this technique of "doin' what comes naturally," as have the HIV retroviruses. (Few are aware that the HIV virus becomes embedded in our DNA.)

A closer look at the issue of general consciousness of genetic manipulation shows that Perdita is still with us. A 1987 survey of public awareness by the Office of Technology Assessment indicated that, at that time, about $40 \%$ of the population was aware that genetic engineering techniques could be used to produce altered plants and animals. Of those who were aware of genetic manipulation, a full one-quarter felt it was morally wrong.

Since that time, the number of people aware of genetic transformation has increased, but opposition has not disappeared and may have expanded due to organized pressure groups such as Jeremy Rifkin's Foundations on Economic Trends, sponsor of the Pure Food Campaign (Fig. 1). In Europe, countries such as Germany have virtually outlawed food products based on genetic transformation. In the United States, products of genetic engineering and biotechnology, such as Bovine Somatotropin (BST) to increase milk production and Calgene's Flavr Savr tomato, which contains an antisense transcript for polygalacturonase, have come under attack despite being given the imprimatur of the Food and Drug Administration.

The 1987 survey also examined the concept that direct manipulation of genetic material was intrinsically different from conventional genetic manipulation through sexual recombination (cross breeding). Astoundingly, although three-quarters of the population had heard of cross breeding, a full $26 \%$ also thought that process morally wrong. The survey concluded that, despite the difference in awareness of the two technologies ( $41 \%$ for genetic transformation vs. $76 \%$ for cross breeding), Americans did not hold different views about the morality of the two approaches. Opposition to both techniques diminished somewhat if the approaches were shown to be risk-free and promised desirable outcomes (e.g., a cancer cure or disease-resistant crops).

Yet, plant breeding, even by conventional techniques, continues to be attacked from many sources. For example, there are many who believe the production of first-generation hybrids is part of a plot by seed companies to eliminate grower-produced seed and a direct threat to biodiversity. The latter concern exists despite the fact that hybrid breeding requires the development of diverse populations from

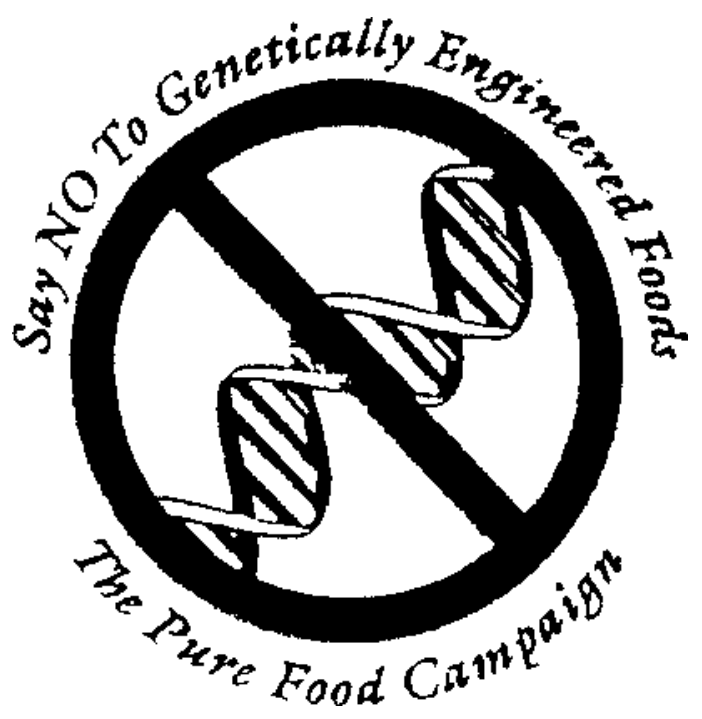

Fig. 1. Logo of the Pure Food Campaign. 
which to extract inbreds. Current interest in heirloom varieties is in one sense nostalgia for the old, but it is also promoted as a rebuke to plant breeding. Consumer dissatisfaction with supermarket tomatoes is directed toward plant breeders, not to the harvest and postharves protocols. (Consumers seem to be unaware that supermarket tomatoes taste fine when vine-ripened.) Regrettably, the greatest threat to plant breeding may be the loss of interest in public breeding programs within our research institutions, even for those minor crops where there is no private activity. Most of our landgrant institutions seemingly have become fatigued with expensive plant breeding programs and have greatly reduced their efforts over the past 20 years.

In one sense, and one sense only, our modern-day Perditas are correct. There is no essential difference between cross breeding and genetic engineering, for science is a continuum. Plant breeders have always been trying to increase the gene pool by breaking the boundaries imposed by sexual recombination. Genetic engineers have found the key, and their discoveries will increase the relevance and importance of plant breeding technology. We are not tampering with Mother Nature, rather we are benefiting from her mysterious and wonderful ways.
What conclusions are to be made 400 years after Shakespeare's handling of the subject? The Office of Technology survey does show that acceptance of change increases with education, but it also shows that the fear of the unknown is real and that science, for all its advances, is treated with skepticism by many. Mary Wollstonecraft Shelley's Dr. Frankenstein, "the mad scientist," continues to be a symbol of fear, and his name has been transformed in the popular imagination to the monster he created. Perhaps we need to consider Polixenes' message to Perdita: to make our gardens rich in gillyvors and quit calling them bastards. I think this is still good advice. 